\title{
The Habeas Corpus Act of 1867: The Supreme Court as Legal Historian
}

\author{
Lewis Mayers
}

On March 18, 1963, the Supreme Court announced Fay v. Noia ${ }^{1}$ and Townsend $v$. Sain, ${ }^{2}$ two decisions which significantly enlarged the availability of federal habeas corpus as a procedure for vacating state criminal convictions. These decisions have been characterized as the culmination of a decade-long process of expansion of that remedy for state prisoners. ${ }^{3}$ In both of them the majority opinions emphasized that, in thus extending the reach of the federal habeas corpus proceeding to provide appellate review of the state court records and retrial of factual issues already determined in the state courts, the Court was merely fulfilling the intent of the Reconstruction Congress in enacting the Habeas Corpus Act of 1867.4 That Congress, the Court said, drafted the act to implement post-Civil War Reconstruction and enforce the new rights established by the post-war constitutional amendments. ${ }^{5}$ To one familiar with the legal landscape of a century ago, these assertions must provoke doubts, which are reinforced on a reading of the text of the act. An examination of the sources consequently seems called for.

The historical inquiry thus proposed is interesting on several additional counts. It is the starting point of the somewhat extraordinary process by which the 1867 statute, after reposing almost quiescent for decades, has proved in more recent years to have been a sleeping giant, capable, when aroused, of laying about with astonishing results. Our

Lewis Mayers, Professor Emeritus of Law, Gity College, City University of New York, is a member of the bars of New York and the District of Columbia. He is the author of The American Legal System (rev. ed. 1964) and received his Doctor of Philosophy degree from Columbia University in 1914 and his Bachelor of Laws degree from George Washington University Law School in 1920.

1372 U.S. 391 (1963) (Brennan, J.; Clark and Harlan, JJ., dissenting).

2372 U.S. 293 (1963) (Warren, C.J.; Clark, Harlan, Stewart and White, JJ., dissenting).

3 See, e.g., Caffrey, The Impact of the Townsend and Noia Cases on Federal District Judges, 33 F.R.D. 446 (1964).

4 See Fay v. Noia, 372 U.S. 391, 416, 420 (1963); Townsend v. Sain, 372 U.S. 293, 312 (1963). The Habeas Corpus Act of Feb. 5, 1867, ch. 28, 14 Stat. 385, is set out in the Appendix.

E See Fay v. Noia, 372 U.S. 391, 415-16 (1963). 
story also illuminates ever so faintly an area of American history which appears to have been somewhat neglected-the process by which the constitutional prohibition of chattel slavery was translated into actual emancipation. It also furnishes an illustration of the way in which an undocumented and seemingly ill-founded historical assertion can, by dint of repetition, gain acceptance even by the Supreme Court. And, finally, it casts a revealing light on the legislative process in Congress a century ago-how a measure drafted in vague terms which made possible far-reaching developments undreamed of at the time was reported only orally, explained in one way in the house in which it originated and in an entirely different way in the other house, and passed without debate and with only the most casual attention in either chamber.

Such a purely historical inquiry can of course make no contribution to the decade-old controversy as to whether federal habeas jurisdiction over state convictions should be curtailed by statute. ${ }^{6}$ That question is to be answered solely in the light of the present-day operation of the remedy. For that purpose, the intentions of the Congress of 1867 are irrelevant-particularly since Congress, by its inaction, may be said to have ratified the Supreme Court's expansion of the federal courts' powers in this field. ${ }^{\top}$

6 In both the 84th and 85th Congresses, the Judicial Conference of the United States sponsored a bill (sometimes referred to as the Parker bill), which passed the House but died in the Senate. The bill would have permitted habeas corpus for convicted state prisoners "only on a ground which presents a substantial Federal constitutional question (1) which was not theretofore raised and determined, (2) which there was no fair and adequate opportunity theretofore to have raised and determined, and (3) which cannot thereafter be raised and determined in a proceeding in the State court, by an order or judgment subject to review by the Supreme Court of the United States on writ of certiorari." H.R. 5694, 84th Cong., 1st Sess. (1955); H.R. 8361, 85th Cong., 2d Sess. (1958). Similar bills in subsequent Congresses have not been reported out of committee, the Judicial Conference having withdrawn its support of the proposal. The Conference has instead sponsored a measure which alters the hearing procedure and sets up standards for review of findings of fact made by the state court, but does not otherwise restrict the remedy. This measure passed the House in the 86th and 88th Congresses, but died in the Senate. H.R. 6742, 86th Cong., 1st Sess. (1959); H.R. 1835, 88th Cong., 1st Sess. (1963). In the present Congress, the measure is still in the House committee. H.R. 5958, 89th Cong., 1st Sess. (1965).

7 Inasmuch as the 1948 revision of the Judicial Code in effect replaced habeas corpus for federal prisoners with a new remedy-the motion to vacate, set aside or correct the sentence (28 U.S.C. $\$ 2255$ (1964))-most of the provisions of the chapter of the Code dealing with habeas corpus (ch. 153) may be regarded as practically significant chiefly for state prisoners. In addition, in enacting as statute the doctrine theretofore adopted by the Court, requiring the exhaustion of state remedies as prerequisite to the grant of federal habeas corpus in behalf of "a person in custody pursuant to the judgment of a State court" ( $\$ 2254)$, the Code for the first time gave statutory recognition to the availability of the writ to a state prisoner whose imprisonment is the result not of a mere charge but of a conviction. 


\section{The Genesis and Adoption of the Statute}

In 1865, when our examination begins, the power of the federal courts $^{8}$ to issue the writ of habeas corpus on behalf of "prisoners in jail" rested on three pieces of legislation: (1) the statute of 1789 relating to federal prisoners; ${ }^{9}$ (2) the statute of 1833 relating to federal officers jailed by a state for acts allegedly done in pursuance of federal law; ${ }^{10}$ and (3) the statute of 1842 relating to aliens held in custody by a state for acts done under the claimed authority of the prisoners' state. ${ }^{11}$

On March 3, 1865, the last day of the 38th Congress, President Lincoln signed a joint resolution which, by declaring wives and children of persons in the armed forces to be free, ${ }^{12}$ purported to confer freedom

8 The Judiciary Act of 1789 , ch. $20, \S 14,1$ Stat. 81 , conferred on all the federal courts created by it the power "to issue writs of scire facias, habeas corpus, and all other writs not specially provided for by statute, which may be necessary for the exercise of their respective jurisdictions, and agreeable to the principles and usages of law"; in addition, the act conferred on "either of the justices of the supreme court, as well as judges of the district courts" (the office of circuit judge not yet existing) power "to grant writs of habeas carpus for the purpose of an inquiry into the cause of commitment." The Supreme Court construed this to mean that a Justice of the Supreme Court or a district judge could issue the writ of habeas corpus in chambers, for the purpose of an inquiry into the cause of commitment, while any federal court, when sitting as a court, could issue the writ, not only to inquire into the cause of commitment, but for any other purpose "agreeable to the principles and usages of law." Ex parte Bollman, 8 U.S. (4 Cranch) 75 (1807). As to the issuance of the writ by the Supreme Court as an exercise of appellate jurisdiction, see note 43 infra. In the acts of 1833 and 1842 the power to issue the writ was conferred only on Justices of the Supreme Court and on district judges, presumably acting in chambers, no court being mentioned as expressly given such power. In the 1867 act, all courts, and the several Justices and judges of those courts, were empowered to issue the writ. See Appendix.

9 Judiciary Act of $1789, \mathrm{ch} .20, \S 14,1$ Stat. 81 .

10 Act of March 2, 1833, ch. 57, $\$ 7,4$ Stat. 634. Because the section comprised part of the "Force Act," enacted to deal with South Carolina's attempted nullification of the tariff, it clearly was intended to apply to state confinement.

11 Act of Aug. 29, 1842, ch. 257, 5 Stat. 539. The statute was occasioned by the international complications resulting from the arrest of an alien by a state. Had the alien claiming the authority of a foreign state been taken into federal custody, he undoubtedly could have successfully invoked the habeas corpus power of the federal courts under the 1789 statute.

12 Joint Resolution 29, March 3, 1865, 13 Stat. 571. Southern resistance to emancipation is illustrated by the reaction in Kentucky, where a considerable number of slaves were liberated. Subsequently several actions for wages for services rendered after the joint resolution were brought in the Kentucky courts by the Freedmen's Bureau on behalf of Negroes allegedly emancipated by the resolution who had continued to serve their former masters. Shaler, Kentucky 366 (Ist ed. 1885). In a decision rendered on December 11, 1865, just one week before the thirteenth amendment became effective, the Court of Appeals of Kentucky declared the joint resolution unconstitutional. Corbin v. Marsh, 63 Ky. (2 Duv.) 193 (1865). Apparently review by the United States Supreme Court was not sought. For indications of the apparent reluctance of slaveholders in Kentucky to emancipate their slaves, see note 17 and text accompanying note 29 infra. 
on a number of slaves in the slave states still in the Union and in areas of the Confederacy not covered by the Emancipation Proclamation. Ratification of the thirteenth amendment was still some months distant.

On December 19, 1865, the day after the thirteenth amendment became effective ${ }^{13}$ and shortly after the opening of the 39th Congress, the House passed without discussion a resolution directing its Committee on the Judiciary

to inquire and report to the House, as soon as practicable, by bill or otherwise, what legislation is necessary to enable the courts of the United States to enforce the freedom of the wives and children of soldiers of the United States under the joint resolution of March 3, 1865, and also to enforce the liberty of all persons under the operation of the constitutional amendment abolishing slavery. ${ }^{14}$

Some three weeks later, on January 8,1866 , the chairman of the House Judiciary Committee introduced a "bill to secure the writ of Habeas Corpus to persons held in slavery or involuntary servitude contrary to the Constitution of the United States." Referred to the Committee on the Judiciary, ${ }^{15}$ the bill read:

Be it enacted ... that all persons who are held in slavery or involuntary servitude otherwise than for crime whereof they are convicted shall be discharged on Habeas Corpus issued by and returnable before any court or judge of the United States; and if the court or judge refuse the discharge the petitioner may forthwith appeal to the Supreme Court, which court if then sitting or if not at its next term shall hear the case on the first motion day after the appeal is docketed and discharge the petitioner if he shall appear to be held in slavery or involuntary servitude contrary to the constitution of the United States. ${ }^{16}$

Although introduced by its chairman, the bill was never reported out of the Judiciary Committee. ${ }^{17}$ Instead, a new measure was drafted and

13 On the very first day of the session, two weeks before the amendment went into effect, Senator Sumner of Massachusetts had introduced "A Bill Supplying appropriate legislation to enforce the amendment to the Constitution prohibiting slavery." S. 6, 39th Cong., 1st Sess. (1865). On March 27, 1866, Senator Doolittle of Wisconsin introduced "A Bill to Provide appropriate legislation to enforce article thirteen of the amendments to the Constitution ...." S. 232, 39th Cong., Ist Sess. (1865). Both bills were adversely reported on by the respective judiciary committees. Cong. GrobE, 39th Cong., Ist Sess. 519, 3277 (1866).

14 Cong. Globe, 39th Cong., 1st Sess. 87 (1865).

15 Id. at 135 .

16 The bill was not printed. The original handwritten bill is in the National Archives.

17 The original version was abandoned despite the efforts of Representative Green C. Smith of Kentucky, who immediately upon the introduction of the bill and its referral to 
combined with a totally unrelated measure for Supreme Court review of state judgments by writ of error. ${ }^{18}$ The resulting combined bill, which with amendments became the statute of 1867, was introduced some four months later by Representative William Lawrence of Ohio and referred to the Judiciary Committee, on which he served.

The section of the bill relating to habeas corpus ${ }^{19}$ provided that "in addition to the authority already conferred by law," the federal courts "shall have power to grant the writ of habeas corpus in all cases where any person may be restrained of his or her liberty in violation of the Constitution, or of any treaty or law of the United States." 20 The bill did not speak, as did the three existing habeas corpus statutes, of "prisoners in jail"; it spoke instead of "any person ... restrained of his or her liberty," a phrase apt for describing an ex-slave held in bondage or peonage. ${ }^{21}$

On July 25, three days before the close of the session, the bill, with amendments, was reported orally to the House and passed. ${ }^{22}$ With a further trifling amendment, ${ }^{23}$ it passed the Senate in the next session of Congress $^{24}$ and became law on February $5,1867 .{ }^{25}$

the committee inquired whether the committee could not report the bill for immediate action by the House, saying: "It is a measure of great importance to many persons in my state." Cong. GlobE, 39th Cong., lst Sess. 135 (1866).

18 H.R. 605, 39th Cong., 1st Sess. (1866). The measure relating to review by writ of error constituted $\S 2$ of the bill (H.R. 605) and of the statute as enacted. Although this section makes no mention of the Judiciary Act of 1789 , it in effect replaced $\S 25$ of that act, the principal change being the deletion of the last sentence of that section reading: "But no other error shall be assigned or regarded as a ground of reversal in any case as aforesaid, than such as appears on the face of the record, and immediately respects the before mentioned questions of validity or construction of said constitution, treaties, statutes, commissions or authorities in dispute." See also notes 54 and 55 infra.

10 H.R. 605, 39th Cong., 1st Sess. $\$ 1$ (1866) (hereinafter referred to as "the bill").

20 Section 1 of the bill was identical with those portions of the statute which are preceded by the numerals [1], [3], and [5] in the copy of the statute given in the Appendix.

21 It is important to note that the references to "prisoners" "in custody" in violation of the Constitution, found in the present statute, Judicial Code, 28 U.S.C. $\$ 2841$ (1964), did not appear in the 1867 act and that their presence in the law today is due to the apparently unnoticed handiwork of the compiler of the revised statutes. The point is of special interest in view of the erroneous references by the courts to "prisoners" and "custody" as being in the 1867 act. See note 65 infra.

22 The committee had on June 29 reported the bill orally, and the bill as amended had without discussion again been referred to the committee. Cong. GlobE, 39th Cong., 1st Sess. 3501 (1866). The amendments made by the committee are the portions of the statute printed in the Appendix preceded by the numerals [4] and [6]. For passage of the act see CoNG. GLOBE, 39th Cong., 1st Sess. 4151 (1866).

23 The amendment, which appears in the statute given in the Appendix following the numeral [2], was intended to make clear that the judges could exercise the power to issue the writ only "within their respective jurisdictions." Cong. Globe, 39th Cong., 2d Sess. 730,790 (1867).

24 Id. at 790.

25 Act of Feb. 5, 1867, 14 Stat. 385 . 


\section{The Purpose of the Statute: Congressional Discussion}

Although there was no debate in either house on the general merits of the bill, apparently questions concerning a proviso in the bill which excluded certain persons then in military custody ${ }^{26}$ from the bill's application evoked statements in each house from the members reporting it on behalf of the Judiciary Committee.

The statement in the House by Representative Lawrence, the presumptive draftsman of the measure, ${ }^{2 \pi}$ was as follows:

On the 19th of December last, my colleague [Mr. Shellbarger] introduced a resolution instructing the Judiciary Committee to inquire and report to the House as soon as practicable, by bill or otherwise, what legislation is necessary to enable the courts of the United States to enforce the freedom of the wife and children of soldiers of the United States, and also to enforce the liberty of all persons..$^{28}$ Judge Ballard, of

26 The second section of the bill, dealing with writs of error from the Supreme Court to state courts, concluded: "This act [though obviously the intended reference is only the first section of the act] shall not apply to the case of any person who is or may be held in the custody of the military authorities of the United States, charged with any military offense, or with having aided and abetted rebellion against the government of the United States prior to the passage of this act." On the bill being reported orally to the House, a member inquired whether this proviso did not "cut off from the benefit of the writ of habeas corpus" a civilian taken into custody by the military authorities. To this Lawrence responded, "I think not. . . This has no relation to that subject at all." He then explained the purpose of the bill, concluding with the statement that the bill "does not interfere with persons in military custody or restrain the writ of habeas corpus at all." The inquiring member was understandably not satisfied, but the bill passed without further discussion. Cong. GLobE, 39th Cong., 1st Sess. 4151 (1866). As to the likely meaning of Lawrence's response, see text at note 34 infra. In the Senate, Senator Davis of Kentucky objected to "such immunity as is given to the military authorities by that bill from having persons taken under military arrest delivered from their custody, and their aggression by a writ of habeas corpus...." In response, Senator Trumbull, who was reporting the bill as chairman of the Senate Judiciary Committee and who apparently was not entirely familiar with it, see notes 36-39 and accompanying text infra, at first declared that the proviso applied only to persons in the military service. On rereading the text of the proviso, however, he declared that its object was "not to interfere at all with any existing condition of persons held in confinement in consequence of the rebellion." Senator Davis being still unconvinced, the bill was, with Trumbull's consent, postponed until the next session. Cong. Globe, 39th Cong., 1st Sess. 4229-30 (1866).

27 Inasmuch as Lawrence introduced the measure, subsequently reported the bill on behalf of the committee in the place of the committee chairman, and was the only member of the committee to speak on the bill, it may be assumed that he was its draftsman. See Cong. Globe, 39th Cong., 1st Sess. 2723 (1866).

28 The resolution referred not to the liberty of "all persons" generally, but only to that of persons "under the operation of the constitutional amendment abolishing slavery." Although in the stress of debate Lawrence omitted this qualification, that he had it clearly in mind is apparent from his going on to say that the federal courts had been held to have no jurisdiction to enforce "the rights and liberties of such persons." (Emphasis sup. plied.) 
the district court of Kentucky, decided that there was no act of Congress giving courts of the United States jurisdiction to enforce the rights and liberties of such persons. In pursuance of that resolution of my colleague this bill has been introduced, the effect of which is to enlarge the privilege of the writ of hobeas [sic] corpus, and to make the jurisdiction of the courts and judges of the United States coextensive with all the powers that can be conferred upon them. It is a bill of the largest liberty, and does not interfere with persons in military custody or restrain the writ of habeas corpus at all. ${ }^{29}$

In thus explaining to his colleagues the purpose of a bill which the Supreme Court today accepts as having been intended to extend the federal habeas jurisdiction to state prisoners, the draftsman of the bill nowhere mentioned prisoners and spoke solely of jurisdiction "to enforce the rights and liberties" of persons just freed from slavery, whether by the earlier joint resolution relating to the wives and children of soldiers or subsequently by the thirteenth amendment. The bill was introduced, Lawrence declared, "in pursuance of" the House resolution of December 19th, which spoke exclusively of such persons and had no reference to prisoners, state or federal. Surely, without its closing sentences not only would Lawrence's statement afford no foundation for the view that the measure was intended to embrace state prisoners, but it would be extremely strong evidence that prisoners, whether state or federal, were not intended to be included. What then is the significance of Lawrence's closing phrases, which the Supreme Court, omitting all mention of Lawrence's express statement of the special and limited purpose of the bill, has declared "leave little doubt as to the breadth of [the bill's] intended scope"?30

Lawrence's statement that the bill would "make the jurisdiction of the courts and judges of the United States coextensive with all the powers that can be conferred upon them," when viewed in the context of his immediately preceding statement about the lack of jurisdiction in the case of freedmen, raises doubt that he had state prisoners in mind at all; he may have intended to convey only that the lack of jurisdiction in the case of freedmen was to be corrected. The federal courts already had habeas jurisdiction of state prisoners in the two situations mentioned. The possibility of any other state prisoner being held in viola-

29 Cong. Globe, 39th Cong., 1st Sess. 4151 (1866).

30 Fay v. Noia, 372 U.S. 391,417 (1963). The citation of these phrases as unmistakable evidence of the purpose of the bill is especially perplexing since the opinion, in the preceding sentence, quotes the House resolution of December 19th, see Conc. GlobE, 39th Cong., Ist Sess. 87 (1865), and expressly states that the measure was introduced "in response to" that resolution. 
tion of the Constitution as it then stood or of any federal law was so remote that it may well not have been present in his mind at all. ${ }^{31}$

The words "it is a bill of the largest liberty," occurring in Lawrence's last sentence, are of special interest. In its desire to attribute marked significance to them, the Court saw fit to omit all mention of the military prisoner proviso ${ }^{32}$ and to quote part of Lawrence's original sentence as a seemingly complete and independent statement; it accomplished this surgery by substituting a period for a comma. ${ }^{33}$ If read in its entirety, Lawrence's last sentence may seem at first glance confused. But if one has in mind the then existing habeas corpus statutes, as he doubtless did, the meaning becomes clear. Persons in federal military custody already enjoyed the privilege of the writ of habeas corpus by virtue of the act of 1789 , although there temporarily remained some persons for whom the privilege was still suspended. ${ }^{34}$ While the bill specifically provided that it should not be applicable to such persons, their rights under the 1789 act, when the suspension would terminate, remained unaffected by the bill, which expressly preserved to the courts the habeas powers "already conferred by law." Thus it was a bill "of the largest liberty" because it extended the federal habeas jurisdiction to freedmen yet in no way constricted the existing federal habeas protection of federal prisoners.

In reporting the bill in the Senate the chairman of the Judiciary Committee, Senator Lyman Trumbull of Illinois, gave a quite different explanation of the purpose of the bill. Making no mention whatever of the House resolution pursuant to which the bill had been drafted and introduced, he said:

[T] he habeas corpus act of 1789 , to which this bill is an amendment, confines the jurisdiction of the United States courts in issuing writs of habeas corpus to persons who are held under United States laws. Now, a person might be held under a State law in violation of the Constitution and laws of the United

31 "The claim that the habeas jurisdiction was to become coextensive with 'all the powers' conferrable by article III of the Constitution seems to me to be largely meaningless." Bator, Finality in Criminal Law and Federal Habeas Corpus for State Prisoners, 76 HARV. L. REv. 441, 477 n.82 (1963).

32 The omission is noted in Mr. Justice Harlan's dissenting opinion, Fay v. Noia, 372 U.S. 391,453 n.7 (1963).

33 Compare Fay v. Noia, 372 U.S. 391, 417 (1963), with Representative Lawrence's concluding sentence, text accompanying note 29 supra.

34 By proclamation of Dec. 1, 1865, Proclamation No. 51, 13 Stat. 774, the existing suspension of the privilege of the writ of habeas corpus in the case of certain military offenders and of "spies or aiders or abettors of the enemy," imposed by the proclamation of Sept. 15, 1863, Proclamation No. 7, 13 Stat. 734, had been terminated in all the loyal states except Kentucky. 
States, and he ought to have in such a case the benefit of the writ, and we agree that he ought to have recourse to the United States courts to show that he was illegally imprisoned in violation of the Constitution or laws of the United States..$^{35}$

Trumbull's apparent ignorance of the purpose of the House bill and his improvisation on the Senate floor of a different explanation of the bill's significance are puzzling. They are explained by his having reported the bill at the request of a member of the House committee ${ }^{36}$ in the closing hours of the session, probably without the bill having been considered in his committee, ${ }^{37}$ and without having himself taken the time to inquire into its genesis in the House. ${ }^{38}$ Presumably he simply drew from the face of the bill the explanation which he offered to the Senate. Subsequent to the enactment of the measure, however, he must have learned of the circumstances attending the framing and introduction of the measure in the House, for two years later he stated on the floor of the Senate that the measure had been enacted to aid the freedman. ${ }^{39}$

35 Cong. Globe, 39th Cong., 1st Sess. 4229 (1866).

30 Trumbull himself stated: "I did not think there would be any objection to the bill. I received a note from one of the members of the Judiciary Committee of the House of Representatives requesting me to have the bill acted upon. ... I do not think there is any just objection to it. I certainly should not wish to have it passed if there was." Ibid.

37 The bill had reached the Senate only on the preceding day, so that any consideration of the bill by the Senate Judiciary Committee could have taken place only on that day. Such consideration, if any, in the closing hours of the Senate was obviously perfunctory. At one point in his effort to satisfy the Senator who objected to the military proviso, Trumbull said: "It is a House bill; it was not prepared in the Senate; we considered the bill, and I am sorry that the Senator from Maryland [Mr. Johnson] is not here; he examined it in committee and is in favor of its passage." Ibid. Curiously, though Trumbull identified Johnson as the member of his committee most conversant with the bill, it was Johnson who, when the bill at the next session again came before the Senate, proposed an amendment on the floor, Cong. Globe, 39th Cong., 2d Sess. 730 (1867), and who, in the discussion in 1868 on the proposed repeal of the provision which gave the right of appeal to the Supreme Court, see note 83 infra, seemed to have difficulty in distinguishing the statute in question from the contemporaneous statute strengthening the right of removal by federal officers of cases instituted against them in the state courts. Cong. Grobe, 40th Cong., 2d Sess. 2096 (1868).

38 His response to the member who interrogated him as to the military proviso is confused and self-contradictory. He had apparently anticipated no objection to the bill. Cong. GLOBE, 39th Cong., Ist Sess. 4229 (1866).

39 In the 1868 Senate debate on the proposed repeal of the provision of the 1867 statute giving the right of appeal to the Supreme Court, Trumbull argued that the 1867 statute had no reference to persons in federal custody, stating: "The act of 1789 authorized the issuing of all such [habeas corpus] writs in cases where persons were deprived of their liberty under authority or color of authority of the United States. Why, then, was the act of 1867 passed? It was passed to authorize writs of habeas corpus to issue in cases where persons were deprived of their liberty under State laws or pretended State laws. It was the object of the act of 1867 to confer jurisdiction on the United States courts in cases not before provided for, and it was to meet a class of cases which was arising in the 
There were in both houses brief remarks on subsidiary features of the measure in addition to those made by its proponents. ${ }^{40}$ In the remarks of the single member who discussed the measure in the House, there is no reference to its possible application to state prisoners and in the remarks of two Senators there are passages apparently indicating an understanding that it would apply to persons in state custody. But there is no indication that the measure was understood to make habeas corpus available to a state prisoner serving a sentence imposed after conviction.

The almost total lack of consideration of the measure in either house is remarkable if the act were intended to be broadly applicable because its provisions departed markedly from those of the existing habeas corpus statutes, raising questions which could not have

rebel States, where, under pretense of certain state laws, men made free by the Constitution of the United States were virtually being enslaved, and it was also applicable to cases in the State of Maryland where, under an apprentice law, freedmen were being subjected to a species of bondage. The object was to authorize a habeas corpus in those cases to issue from United States courts . . . " Cong. Globe, 40th Cong., 2d Sess. 2096 (1868).

40 In the House, the member who had questioned the effect of the proviso excepting persons in military custody from the application of the measure complained that "it is exceedingly difficult for us to understand the scope of the bill," which was the last of fifteen measures reported by the Judiciary Committee in the hour allotted to it; and when the chairman of the committee asked unanimous consent for an additional hour's time, this member felt "compelled to object, from the fact that we have no opportunity to consider and understand the bills that are brought in here." Cong. GLOBE, 39th Cong., 1st Sess. 4151 (1866). In the Senate, Senator Davis of Kentucky said: "As I gather the contents of the bill as it was read, there is a provision to prevent a person that has been discharged by a United States court upon a writ of habeas corpus from being taken again by the authority of the State Courts or the State laws.... I am not satisfied that the provisions against rearrest by the State authorities are not altogether too stringent . . . I Id. at 4229. And at the next session of Congress, Senator Johnson of Maryland referred several times to prisoners confined in distant states; but the context indicates that he had federal prisoners in mind. Presumably, however, he understood the measure to include state prisoners as well. Cong. GLoBe, 39th Cong., 2d Sess. 730 (1867).

When the bill came up for final action in the Senate in January 1867, there was ample time for consideration since the session of Congress still had more than a month to run. However, no one called attention to the bill's careless draftsmanship, which had caused the proviso relating to persons in military custody, applicable only to the section of the bill relating to habeas corpus, to be placed at the end of the section relating to Supreme Court review of state judgments and declared applicable to the entire act. That the confusion survives is evidenced in an account of the history of the appellate jurisdiction of the Supreme Court which includes the proviso in a reproduction of $\$ 2$. ROBERTSON \& Kirkham, The Jurisdiction of the Supreme Court of the United States 932-33 (2d ed. Wolfson \& Kurland 1951). Quite aside from the genesis of the bill and the draftsman's explanation of its purpose, its negligent draftsmanship and the indifference exhibited toward it by even the Senate Judiciary Committee make it difficult to believe that there was a congressional intention "to take up general revision of the habeas corpus jurisdiction" as is imputed in Bator, Finality in Criminal Law and Federal Habeas Corpus for State Prisoners, 76 HARv. L. REv. 441, 475 n.80 (1963). 
failed to arouse attention on close examination of its text. ${ }^{41}$ Still more striking was the failure of any member to question the provisions for determination of issues of fact which were included in the bill but were totally absent from the 1789 and 1833 statutes and found only in minor part in the 1842 statute. In a completely novel provision, the 1867 bill set short time limits on the making of the return, with a hearing to be held within five days thereafter. Provision was made for denial of the allegations of the return under oath and for the amendment of the return "that thereby the material facts may be ascertained." The court was then to "proceed in a summary way to determine the facts of the case, by hearing testimony ...."

But perhaps most surprising, if prisoners were embraced within the measure, was the failure to recognize that the new act overlapped the act of 1789. That act did not expressly state the grounds on which a person in federal custody could be discharged, but clearly he could be released if confined "in violation of the constitution, or any treaty of law of the United States." 42 Under the 1789 measure no review as of right $t^{43}$ by the Supreme Court was available to him; under the new measure it was. The confusion which was bound to arise promptly occurred in the celebrated McCardle case. ${ }^{44}$

41 E.g., where all the previous statutes had spoken of the "prisoner," the bill spoke of "any person restrained of his or her liberty."

42 This overlap was not eliminated even in the very competent revision of the Judicial Code made in 1948. The Code still lists prisoners "in custody under or by color of the authority of the United States" as in a class separate from and coordinate with those "in custody in violation of the Constitution or laws or treaties of the United States," 28 U.S.C. $\$ 2241$ (1964), as if to make habeas corpus available to one in custody under the authority of the United States even if his custody is not in violation of the Constitution or laws.

43 Although the Judiciary Act of 1789 did not include habeas corpus proceedings among those which could be reviewed by the Supreme Court on writ of error ( $\$ 22,1$ Stat. 84), the Court early held that it could nevertheless, in the exercise of its appellate jurisdiction, make use of its power to grant the writ of habeas corpus and the writ of certiorari (the latter writ being necessary to the exercise of the Court's jurisdiction and "agreeable to the principles and usages of law,") to discharge a prisoner where he was confined under order of a federal court. Ex parte Bollman, 8 U.S. (4 Cranch) 75 (1807). For the subsequent development of this procedure by the Court to include cases in which the confinement of the petitioner was not under order of a federal court but had been reviewed by a lower federal court on habeas corpus, see Oaks, The "Original" Writ of Habeas Corpus in the Supreme Court, 1962 SUPREME Court Rev. 153, 165-207.

44 McCardle, having unsuccessfully sought release by habeas corpus from military imprisonment imposed by a military court acting under the Military Government Act of 1867, appealed to the Supreme Court on the basis of the 1867 habeas statute. The government moved to dismiss the appeal, contending that the 1867 statute was not intended to apply to persons in federal custody who were already covered by the 1789 statute. The Supreme Court found the 1867 statute applicable and held that the appeal was properly before it. Ex parte McCardle, 73 U.S. (6 Wall.) 318 (1868). Before the Court had announced its decision on the merits of the appeal, however, its appellate jurisdiction under the 
Such then is the congressional history of the measure-presentation without written report on the floors of both houses and enactment without discussion of its purposes in either house other than the explanation offered by the member reporting it, with its proponent in the Senate ignorant of both its genesis and of the explanation offered by its draftsman on the floor of the House. Although the Supreme Court has been able to find in this legislative history a clear congressional intention to create a novel form of federal review of state convictions, ${ }^{45}$ it is impossible to speak confidently of the intent of even the two or three members of Congress most intimately concerned with enactment of the measure. ${ }^{46}$

Nor do we have, to throw light on the congressional intent, professional comment such as might be expected to have been forthcoming had the measure been regarded as important by the bar. Although the bill, having passed the House, remained awaiting Senate action for several months while Congress was in recess, a search of the legal peri-

1867 act was withdrawn by Congress. Act of March 27,1868 , ch. $34, \S 2,15$ Stat. 44 . The constitutionality of this withdrawal of jurisdiction was upheld by the Court in Ex parte McCardle, 74 U.S. (7 Wall.) 506 (1869). The Court's statutory jurisdiction was restored in 1885. Act of March 3, 1885, ch. 353, 23 Stat. 437.

45 The Court asserts that the "legislative history" of the measure "lends support" to "this conclusion." Fay v. Noia, 372 U.S. 391, 416 (1963). The conclusion in question is not precisely identified, but seemingly the reference is to the statement, some lines earlier, that the measure "seems plainly to have been designed to furnish a method additional to and independent of direct Supreme Court review ...." The only item of the legislative history adduced by the Court is the inaccurate quotation, out of context, of two sentences in the obviously confused remarks of Lawrence in reporting the bill. See text at notes 30-33 supra. Neither sentence makes any reference to Supreme Court review, or to any alternative thereto. By contrast, Judge Wyzanski has concluded that "there was nothing in the avowed purpose or legislative history of the 1867 statute, which compelled the Supreme Court of the United States to interpret the statute as conferring upon United States District Judges authority to inquire whether a state court judgment by a jurisdictionally competent court rested upon any procedural step or substantive ruling violative of the Constitution of the United States." Geagan v. Gavin, 181 F. Supp. 466, 468 (D. Mass. 1960).

46 In addition to the proceedings in Congress in connection with the enactment of the 1867 act, subsequent statements in Congress as to the purpose of the measure, like that of Trumbull, see note 39 supra, are to be found in the 1868 debate on the proposed repeal of the provision on the 1867 act conferring appellate habeas jurisdiction on the Supreme Court. These statements, like Trumbull's, were made in the course of an intensely partisan debate, and must be evaluated accordingly. It may be significant, however, that Representative Hubbard of Connecticut, who strongly denounced the proposed repealer, agreed with the statement made by Wilson, Chairman of the Judiciary Committee and sponsor of the repealer, that the purpose of the measure was to protect the freedman from the apprentice and like laws of the former slave states. CoNG. GLOBE, 40th Cong., 2d Sess. 2168 (1868). In the Senate, Buckalew of Pennsylvania, a Democrat, who delivered the principal speech in opposition to the repealer, declared that the 1867 measure was an integral part of the Republican plan of military government of the South. Id. at 2125. For the lack of foundation for such a contention, see text at notes 67-78 infra. 
odicals of the day has failed to yield a single reference to the bill before or after its enactment. Contemporary treatises on habeas corpus accord the enactment perfunctory mention, with no comment on its purposes. ${ }^{47}$

In view of the meagerness of the congressional sources and of absence of professional comment, one must turn to the measure itself to determine whether it was the intent of the draftsman to create a new federal remedy of a scope far wider than he disclosed to his colleagues.

\section{The Purpose of the Statute: The Internal Evidence}

If one were drafting a statute in 1866 to extend the federal habeas jurisdiction to state prisoners, the most natural measure would have been a bill modeled upon the existing three habeas statutes relating specifically to "prisoners in jail" or, more simply, a bill merely deleting the existing provision restricting the federal habeas power to prisoners "in custody under or by colour of the authority of the United States." If, on the other hand, one had in mind both state prisoners and freedmen kept in bondage by their former masters, the most natural course would have been to draft two separate provisions; an unlikely approach would be a wholly novel formula which omitted the word "prisoner" and overlapped the existing provisions.

If, however, only ex-slaves were intended, why did not the measure specifically treat, as did the previous measure introduced by the chairman of the Judiciary Committee, persons "held in slavery or involuntary servitude"? Why use the more general phrasing of the Lawrence bill, "any person restrained of his or her liberty in violation of the constitution"? An explanation perhaps is to be found in the legislative developments in the former Confederate states in the months following the introduction of the earlier bill. The newly constituted legislatures of those states, following the example of the loyal state of Maryland, which had in 1864 concurrently abolished slavery and enacted oppres-

47 Apparently the only treatise on habeas corpus in print at the time of the enactment of the measure was that of Hurd. When issued in a revised edition in 1876, it presented the 1867 statute, without comment, in a footnote. Hurd, A Treatise on Personal Liberty AND HABEAs CoRPus 135 (2d ed. 1876). Indeed, an exhaustive study of the federal judicial system published more than half a century later fails even to mention the statute. Frankfurter \& Landis, The Business of the Supreme Court: A Study in the Federal Jubrcial SYSTEM (1928). This omission is the more surprising in view of the senior author's perception, twenty-five years later, that Congress intended to give the district courts broad powers of review of state convictions. See note 101 infra. As early as 1883 the exercise by the lower federal courts of their power under the 1867 statute in the cases of state prisoners, at a time when the Supreme Court's appellate jurisdiction under that statute had not yet been restored, was beginning to come under attack both in Congress and in the professional literature. Cf. H.R. Rep. No. 730, 48th Cong., Ist Sess. (1884); Thompson, Abuses of the Writ of Habeas Corpus, 6 A.B.A. REP. 243 (1883). 
sive apprenticeship laws for Negroes, ${ }^{48}$ were striving to impose a new bondage on the freedman by contract labor statutes carrying criminal penalties for breach of contract and by broadly phrased vagrancy and apprenticeship laws. ${ }^{49}$ Quite possibly it was thought that one seeking relief through habeas corpus from detention under such vagrancy or contract labor statutes would find the broader phrase, "restrained of his liberty in violation of the constitution," more serviceable than the narrower "held in slavery or involuntary servitude."

Although the measure also spoke of restraint of liberty contrary to any "law" of the United States, it is doubtful that this indicated that state prisoners generally were meant to be protected. Other than the recently enacted Civil Rights Act there were no federal laws which protected the state criminal defendant, unless he had been acting under federal authority; and for that individual the act of 1833, providing not only federal habeas corpus but also the right of removal to the federal court, already furnished ample protection when reinforced by acts of $1863^{50}$ and 1866.51 On the other hand, to hold a freedman in restraint of his liberty under a state law discriminating against Negroes, as did the new legislation of the late Confederate states, was a violation of the Civil Rights Act; hence that law may well have been in the mind of the draftsman.

The reference in the bill to one restrained of his liberty in violation of "any treaty of the United States" is difficult to explain on any theory. It had of course no application to an ex-slave. As to a state criminal defendant, the act of 1842, passed expressly to make federal habeas corpus available to one acting for a foreign government, was still in force; no occasion for further protection had arisen. Thus there seems no reason for a reference to treaties if the bill contemplated only the ex-slave or the state prisoner. The likely explanation seems to be that, once violation of the Constitution and laws came to mind, the completion of the conventional triad followed almost automatically. It is perhaps significant that in drafting the amendments which were added when the bill was first reported by the Judiciary Committee, the draftsman omitted all reference to treaties in the three provisions in which he mentioned restraint of liberty "in contravention of the constitution or laws of the United States."

Even the possibility of a state prisoner being held in violation of the Constitution was remote. The Constitution in 1866 contained no

48 See note 80 infra.

49 Franklin, From Slavery to Freedom 299 (1948). See also note 39 supra.

50 Act of March 3, 1863, ch. 81, 12 Stat. 755.

51 Act of May 11, 1866, ch. 80, 14 Stat. 46 . 
provision protective of the state criminal defendant against procedural injustice other than the prohibition against bills of attainder. No state conviction had ever been set aside by the Supreme Court on any ground other than that the statute creating the defendant's offense was an unconstitutional invasion of powers reserved to the national government or in conflict with exercise of the federal power. There was thus in effect no possibility of a state prisoner being held in violation of a constitutional procedural right. The extension of federal habeas corpus to state prisoners in 1833 and 1842 had been made in response to immediate necessity. Was the 1867 extension, by contrast, made in a vacuum, with not even a remote contingency in mind?52

The Judiciary Act of 1789 gave the Supreme Court the authority to review as of right the constitutionality of a state statute on which a prosecution was founded, and there is no evidence that this procedure had been found unsatisfactory. ${ }^{53}$ Indeed, the 1867 statute itself in its second section provided for the enlargement of the power of the Supreme Court in disposing of cases coming to it from the state courts on writs of error; ${ }^{54}$ yet no one in the discussion in either house suggested a connection between the two sections. 55

Doubt that the statute was intended to enlarge federal review of state convictions increases when one reflects that the right of the state criminal defendant to have his conviction reviewed by the Supreme Court was already greater than that enjoyed by the federal criminal defendant. A person convicted of a federal crime, usually in a court presided over only by a district judge, had no right of appeal. ${ }^{56}$ Not even the claim of

52 See text following note 82 infra for the lack of connection between the act and the adoption of the fourteenth amendment.

53 Even eight years after the passage of the statute, Mr. Justice Bradley, sitting as a circuit judge, on discovering that the language of the statute seemingly authorized the discharge by an inferior federal court of a state prisoner convicted under an unconstitutional statute, observed that "it might ... be a wise amendment of this law, to provide that in all cases after conviction, the party should be put to his writ of error to the supreme court of the United States." Ex parte Bridges, 4 Fed. Cas. 98, 106 (No. 1862) (C.C.N.D. Ga. 1875). (Emphasis added.)

54 In addition to the change mentioned in note 18 supra, the act authorized the Court to "proceed to a final decision . . . and award execution" instead of remanding the case to the state court. The original Judiciary Act (\$25) had authorized this only in cases where the Court had on a previous occasion already remanded the case to the state court.

55 It seems incomprehensible that such a connection should not have been pointed out by the proponents of the measure if, as declared in the Noia opinion, the measure "seems plainly to have been designed to furnish a method additional to and independent of direct Supreme Court review of state court decisions . . . " 372 U.S. 391, 416 (1963).

56 The Judiciary Act of 1789 made no provision for appeal in criminal cases. The first such provision was made in the Act of March 3, 1879, ch. 176, 20 Stat. 354, providing for appeal from the district court to the circuit court in certain cases. However, by Act of April 29, 1802, ch. 31, $\$ 6,2$ Stat. 159, it had been provided that the circuit court was empowered, upon division of opinion, to certify questions to the Supreme Court. 
the federal defendant that the statute under which he was convicted was unconstitutional could be brought before the Supreme Court.

Furthermore, the 1867 statute was amended in the following year to withdraw from the Supreme Court the appellate jurisdiction given it by the statute. ${ }^{5 \tau}$ The purpose of the amendment was to prevent the Supreme Court from passing upon the constitutionality of the Reconstruction Act of $1867 . .^{58}$ But that purpose could as easily have been accomplished by withdrawing the statutory appellate jurisdiction of the Court only in habeas proceedings instituted by persons in federal custody. If protection of the state prisoner were the purpose of the statute, why leave him at the mercy of the district judge ${ }^{59}$ by depriving the Supreme Court of jurisdiction in all proceedings under the statute, and why neglect for nearly twenty years, until long after the occasion for withdrawal had passed, to restore his right of review by the Supreme Court? ${ }^{60}$ Why did not Lawrence, or any other member of the sponsoring judiciary committees if he were concerned with protecting the state prisoner, object to the form of the amendment? Why did none of them, when the occasion had passed, move to restore the Court's jurisdiction?

If protection against state criminal proceedings were one of the purposes of the draftsman, it is surprising that he did not in some manner co-ordinate the text of the measure with the Civil Rights Act of 1866 , which was contemporaneously reported by the House Judiciary Committee and enacted by Congress two weeks before the habeas measure was introduced. The Civil Rights Act, ${ }^{61}$ several months before the fourteenth amendment passed Congress and more than two years before it was ratified, purported to confer citizenship on the Negro and to insure all citizens the equal protection of the laws. It provided, as protection against violation of its prohibitions by state authorities, a remedy more sweeping and more effective than habeas corpus-removal

\footnotetext{
57 "That so much of the act approved February five, eighteen hundred and sixty seven ... as authorizes an appeal from the judgment of the circuit court to the Supreme Court of the United States, or the exercise of any such jurisdiction by the Supreme Court on appeals which have been or may hereafter be taken, be, and the same is, hereby repealed." Act of March 27, 1868, ch. 34, § 2, 15 Stat. 44.

58 See note 44 supra.

59 Although the circuit court in each district consisted of the district judge and the Supreme Court justices "allotted" to the circuit, the increasing inability of the justices to leave Washington, owing to the press of business in the Court, resulted in the circuit court often being held by the district judges alone. FrankFurTer \& LANDIs, op. cit. supra note 47 , at 69 . The office of circuit judge was not created until the following year. Act of April 10, 1869, ch. 22, \& 2, 16 Stat. 44.

60 Act of March 3, 1885, ch. 353, 23 Stat. 437.

61 Act of April 9, 1866, ch. 31, 14 Stat. 27.
} 
of the state proceeding to the federal court. ${ }^{62}$ Indeed, if protection of persons held as prisoners in violation of federal rights had been contemplated by the draftsman of the Habeas Corpus Act, not merely coordination of his bill with the Civil Rights Act but actual incorporation of the new procedure into that act by amendment would have been the natural course.

But it is the novel provisions for speedy and summary disposition of issues of fact that raise the most crucial questions regarding the intent of the draftsman. In the then conventional pattern of the habeas corpus proceeding on behalf of a prisoner held pending trial, determination of issues of fact was almost unknown. The writ was addressed to the jailor, who made a return reciting whether he held the prisoner under authority of an arrest or a commitment after preliminary examination. Refusal to make a return, against which the 1867 act specifically provided, was virtually unknown. The making of a false return, specifically prohibited under penalty by the 1867 measure, was equally rare, so that there was no occasion for the prisoner to traverse the allegations of the return-a step for which the 1867 measure also made specific provision. The sole question before the court was the formal legality of the detention. There was thus no more occasion for the taking of testimony and summary ascertainment of "material facts" in the case of state than of federal prisoners, for whom no such provision had ever been found necessary. A plausible explanation of the provision for determination of fact which is consistent with the genesis of the bill is that the draftsman envisaged a habeas proceeding instituted on behalf not of a prisoner but of an ex-slave allegedly "restrained of his liberty" under an apprenticeship or contract labor statute. In such a proceeding $^{63}$ the desirability of provisions for the prompt making of a return by the employer and for punishing refusal to make a return or making a false return is self-evident. Equally self-evident is the propriety of the provisions for speedy determination of the issues of fact; the petitioner's right to discharge could not, as in the case of a prisoner under judicial commitment, be determined upon the face of the return. ${ }^{64}$ In such a

62 Act of April 9, 1866, ch. 31, § 3, 14 Stat. 27.

63 The first proceeding instituted under the 1867 act was such a proceeding. See note 80 infra.

64 In the Noia opinion, it is stated that "provision for the trial of fact . . had been left unmentioned in the previous statutes governing federal habeas corpus." 372 U.S. 391 , $416 \mathrm{n} .27$ (1963). The statute of 1842, however, had expressly provided for the trial of an issue of fact which could not be met by the jailer's return-whether the petitioners were in fact "subjects or citizens of a foreign state, and domiciled therein," and whether the act for which they were in custody had in fact been "done or omitted under any alleged right, title, authority, privilege, protection, or exemption, set up or claimed under 
proceeding, moreover, possible review by the Supreme Court-a review not available under the 1789 statute-would insure definition by that tribunal, rather than by local federal judges in the former slave states, of the meaning of the new constitutional prohibition of "involuntary servitude."

The measure, as already noted, nowhere speaks of the petitioner as being a "prisoner." 65 It does declare that a "proceeding against such person so alleged to be restrained of his or her liberty in any State court, or by or under the authority of any State, for any matter or thing" at issue in the habeas proceeding is void, not only pending the determination of the habeas proceeding but after the petitioner's discharge as well. The habeas proceeding under the 1867 act was thus intended to be a final resolution of the petitioner's right to freedom. The provision was a significant deviation from usual habeas proceedings by which a person who was entitled to discharge because he had been improperly arrested without a warrant was subject to rearrest on a warrant. ${ }^{66}$ The finality of the decision under the 1867 act also supports the conclusion that the act was not drafted for the states' ordinary prisoners.

\section{The Statute and the Reconstruction Acts}

During the period between the introduction of the bill in the House and its passage in the Senate, concern for the condition of freedmen, which was the sole preoccupation of the sponsors of the bill, was secondary to congressional interest in the political questions connected with the readmission of the representatives of the seceded states to Congress and the extension of the suffrage to the now free Negro population of those states. ${ }^{67}$ There was also strong congressional interest in the prob-

the commission, or order, or sanction, of any foreign State or Sovereignty . . . . Act of Aug. 29, 1842, ch. 257, 5 Stat. 539.

65 Because the provisions of the 1867 statute are printed in the Revised Statutes in a section which also includes the provisions of the three previous habeas statutes, all of which used the term "prisoner," the whole section being made applicable only to "a prisoner in jail," REv. STAT. $\$ 753$ (1875), it is sometimes incorrectly stated that the 1867 statute used that term. Cf. Fay v. Noia, 372 U.S. 391, 452 (1963). In Geagan v. Gavin, 181 F. Supp. 466, 468 (D. Mass. 1960), the 1867 act is incorrectly stated to have conferred on the federal courts authority to grant habeas corpus to "a state prisoner "in custody in violation of the Constitution ... of the United States." "The word "custody" appears at two places in the 1867 statute: in the provision requiring that the petitioner for habeas corpus shall set forth, among other things, "in whose custody he or she is detained," and in the provision authorizing the Supreme Court, in connection with appeals to that Court under the act, to prescribe "regulations and orders, as well for the custody and appearance of the person alleged to be restrained of his liberty," as for other formal matters connected with an appeal to the Court.

66 See Oaks, Habeas Corpus in the States-1776-1865, 32 U. CHI. L. REv. 243, 245 \& n.9 (1965) (citing authorities).

67 Representation of those states and of the loyal former slave states in the House, and correspondingly their share in the electoral college, would be substantially increased 
lem of insuring the physical safety of loyal citizens, federal officials, volunteers connected with the Freedmen's Bureau, and Negro soldiers in the face of the hostile activities of many southern citizens and the unwillingness or inability of the newly reconstructed state governments to furnish protection. It was these problems which were responsible for the creation, early in the 39th Congress, of the Joint Committee of Reconstruction, which was shortly to draft the fourteenth amendment and the Reconstruction Act imposing military government on the states of the late Confederacy.

How distinct the special problem of affording the freedman a federal judicial remedy against oppressive apprenticeship and labor contract laws was from the larger problems of the political reconstruction of the rebel states appears clearly from the facts that the problems of reconstruction were not mentioned in congressional discussions of the habeas corpus bill and that reference was never made to the habeas corpus bill in the extensive congressional debates on the reconstruction measures. Nevertheless, the undocumented assertion has repeatedly been made that the 39th Congress enacted the habeas act to help the federal authorities in dealing with the resistance it anticipated to the reconstruction legislation. ${ }^{68}$ This assertion has now found a place in the magisterial historiography of a Supreme Court opinion which stresses the supposed relation of the statute to the reconstruction program as throwing light on the purposes and scope of the statute. ${ }^{69}$

by the necessity of giving full proportional weight to their whole populations in the next reapportionment, instead of as formerly a weight of only three-fifths to "other persons," unless, of course, the Constitution should in the meantime have been amended.

68 The assertion was originally made by an eminent historian of the Supreme Court and has since been repeated by respected commentators. See 2 WArren, The Supreme CourT in United States History 465 (rev. ed. 1953) (giving no authority); HaRT \& Wechsler, The Federal Courts and The FEDeral System 1237 (1953) (The act was "enacted in anticipation of Southern resistance to the legal measures following the Civil War.") (citing WARREN); Collings, Habeas Corpus for Convicts-Constitutional Right or Legislative Grace?, 40 CALIF. L. REv. 335, 351 (1952) (The act was "enacted to facilitate enforcement of the Reconstruction Acts ....") (giving no source); Reitz, Federal Habeas Corpus: Impact of an Abortive State Proceeding, 74 HARv. L. Rev. 1315, 1325 (1961) (citing HART \&. WECHSLER); Note, The Freedom Writ-The Expanding Use of Federal Habeas Corpus, 61 Harv. L. REv. 657, 659 (1948) (citing WarreN). See also Bator, Finality in Criminal Law and Federal Habeas Corpus for State Prisoners, 76 HARv. L. REv. 441, 475 n.80 (1963) ("There is no clear indication what moved the Congress ... (though surely the underlying concern was the enforcement of the reconstruction legislation)"-the writer not only cites no source for the parenthetical statement but gives source material which seems to contradict it.); Brennan, Federal Habeas Corpus and State Prisoners: An Exercise in Federalism, 7 UTAH L. REv. 423, 426 (1961) (no reference given to support contextual implication that the $\mathbf{1 8 6 7}$ act was framed in anticipation of Southern resistance to Reconstruction); Note, Federal Habeas Corpus for State Prisoners: The Isolation Principle, 39 N.Y.U.L. REv. 78 n.4 (1964) (citing WARREN).

69 The measure is to be "viewed against the background of post-Civil War efforts in Congress to deal severely with the States of the former Confederacy . . . Congress was 
In none of the writings in which this historical statement is made is there any attempt at an explanation why the habeas statute was thought necessary or how it was expected to help the federal authorities in dealing with resistance to reconstruction. ${ }^{70}$ No indication is given of the types of hostile state action, aside from those already amply provided against by the Civil Rights Act and legislation protecting federal officers, which were envisaged by the draftsman and against which the habeas statute would afford protection. The habeas remedy was useless as a protection against physical violence; it could be of value only in the case of a person charged with infraction of a state statute claimed to be violative of the Constitution. How minimal was this possibility would seem to be indicated by the fact that the first such reported case in the South did not arise until eight years after the enactment of the habeas statute, when reconstruction had been virtually completed. ${ }^{71}$ No other reported case in which a person in state custody invoked the statute in any of the southern states during the reconstruction period has been found. To the extent that the possibility might be thought to exist, however, it had already been provided against by the Givil Rights Act.

anticipating resistance to its Reconstruction measures . . . ." Fay v. Noia, 372 U.S. 391, 415 (1963). No citation is given. It is also stated that the measure was "debated and enacted at the very peak of the Radical Republicans' power ...." Id. at 415. Insofar as the measure may be said to have been debated at all, the debate took place in the first session of the 39th Congress, while the moderates were still in control. C $f$. 5 RHodes, A History of THE UNITEd STATES FROM THE CoMpromise of 1850, ch. XXX (1904). The postponement of the enactment of the measure to the second session, when the radicals assumed control, was purely coincidental. See text preceding note 25 supra. As to the lack of evidence that the Joint Committee on Reconstruction, which controlled the Radical Republicans' strategy, had any interest in the measure, see text at note 75 infra.

70 Warren states, without reference to authority, that the measure was "enacted by Congress for the protection of Federal officials and other loyal persons against adverse action by the Courts and officials in the late Confederate states." 2 WARREN, op. cit. supra note 68 , at 466 . But federal officers were already amply protected by existing legislation. It is possible that Warren's reference to "loyal men" is based on a statement in the government's brief in support of its motion to dismiss McCardle's appeal to the Supreme Court, see note 44 stupra, that the purpose of the 1867 act was to "to protect loyal men in the rebel States from oppression under color of state laws administered by rebel officers; to protect especially those who had formerly been slaves ...." Ex parte McCardle, 73 U.S. (6 Wall.) 318, 322 (1867). Trumbull was one of the counsel for the government; hence it is interesting that, in stating the purpose of the 1867 statute in the Senate some months later, see note 39 supra, while mentioning ex-slaves he made no mention of "loyal men." If protection of loyal men was indeed intended, it is difficult to understand why the House committee delayed until the very end of the session in reporting the measure and why Trumbull himself acquiesced so readily in its going over to the following session, still five months in the future; the urgency of the need for additional protection of loyal men was repeatedly before Congress during the session and was the subject of several resolutions in both houses. It seems likely that the emphasis on "loyal men" was developed retrospectively, to convince the Court that it ought not come to the aid of the "rebel" McCardle.

71 Ex parte Bridges, 4 Fed. Cas. 98 (No. 1862) (C.C.N.D. Ga. 1875). 
The "putative father" of the Civil Rights Act, ${ }^{72}$ and the man who piloted it through Congress and over a presidential veto, was Senator Trumbull, the chairman of the Senate Judiciary Committee. Yet, when he was called upon a few months later to improvise an explanation of the purpose of the habeas bill, which his committee was reporting to the Senate at the request of the House committee, it did not occur to him to relate the bill to the recently enacted Civil Rights Act or to possible resistance to that act. ${ }^{73}$

The Reconstruction Act, which became law over the President's veto on March 2, 1867, had been introduced in Congress the day before the habeas bill became law. It grouped the former Confederate states, Tennessee excepted, into five military districts. The commanding general of each district was specifically directed by the act "to protect all persons in their rights of person and property" and was empowered to punish all offenders and to "organize military commissions or tribunals for that purpose"; "all interference under color of State authority with the exercise of military authority" was declared to be "null and void."74 Clearly the military governor did not require the aid of the federal courts in his district to procure the liberation of anyone imprisoned by state officials or state courts in an effort to resist reconstruction. There is no evidence that the Joint Committee on Reconstruction was even aware of the pendency of the habeas measure. Had the habeas bill come to the attention of that committee, its members would doubtless have insisted that it be modified to make clear that it had no application to persons who might be arrested by the military commissions. ${ }^{75}$

As it turned out, the habeas act, instead of aiding the military government in dealing with southern resistance, hindered it. By extending the habeas jurisdiction to the circuit courts, by reciting expressly the grounds on which the writ might be issued, by providing for a speedy return and a prompt hearing, and, most important, by investing the Supreme Court with a statutory appellate jurisdiction theretofore absent, the new statute actually gave aid to those who might be imprisoned by the military for resisting reconstruction. ${ }^{76}$

72 Flack, The Adoption of the Fourteenth Amendment 21 (1908).

73 Cong. Globe, 39th Cong., lst Sess. 4228 (1866).

74 Act of March 2, 1867, ch. 153, § 3, 14 Stat. 428.

75 The provision of the habeas act excepting persons in military custody applied only to a person "charged with any military offense" or charged "with having aided or abetted rebellion against the government of the United States prior to the passage of this act." (Emphasis added.)

76 This was dramatically illustrated in the case of the resister McCardle, see note 44 supra, which caused Congress retroactively to withdraw from the Supreme Court the appellate jurisdiction which the $\mathbf{1 8 6 7}$ act had conferred upon it. However, Congress did not think to prohibit the Court from continuing to review denials of habeas corpus by the 
Inasmuch as the problems of reconstruction were prominently re. ported throughout 1866 and 1867, one would expect the passage of the habeas act to have been noted in the press had the act been related to those problems. But search has failed to yield any reference to it in the most likely media; ${ }^{77}$ nor do the principal historians, in their examination of the contemporary sources, appear to have found mention of it.78

In summary, the available contemporary data yield nothing whatever to connect the habeas act with the reconstruction legislation.

\section{The Statute and the Fourteenth Amendment}

The Noia opinion goes beyond the supposed connection of the habeas act with the anticipated resistance to reconstruction. It declares, without citation to sources, that in enacting the statute Congress "was planning the implementation of the post-war constitutional amend. ments" and that the statute was designed "for the vindication of the new constitutional guarantees." 79 As already seen, the statute was indeed drafted to implement the thirteenth amendment and, moreover, was promptly invoked for that purpose in the first case reported under it. ${ }^{80}$

procedure described in note 43 supra, and the following year, in Ex parte Yerger, 75 U.S. ( 8 Wall.) 85 (1868), the Court accordingly asserted its unimpaired jurisdiction to review a denial of habeas corpus to a prisoner held by a military government commission in Mississippi. No subsequent review on the merits was had in this case.

77 Neither the New York Times nor the New York Tribune made any comment on the act.

78 The works examined were Dunning, Reconstruction, Political and Economic, 18651877 (1907); Fleming, SEQUel to Appomattox (1920); OBerholtzer, A History of the United States Since the Civil War (1917); RHodes, A History of the United States from the Compromise of 1850 (1904); and Stampp, The Era of Reconstruction, 18651877 (1964).

79 Fay v. Noia, 372 U.S. 391, 415-16 (1963). Mr. Justice Brennan, the writer of the opinion, had already made a similar statement in an academic lecture. "In 1867, Congress was anticipating Southern resistance to ... the implementation of the post-war constitutional Amendments. The extension in that year to state prisoners of the federal habeas corpus remedy bespoke congressional unwillingness to trust direct appellate review of state court. decisions by the Supreme Court as the lone avenue to vindication of the new constitutional strictures." Brennan, Federal Habeas Corpus and State Prisoners: An Exercise in Federal. ism, 7 UTAF L. REv. 423, 426 (1961). In lieu of documentation of these and other equally positive assertions, the reader is assured that "anyone delving into the history of the times must be persuaded" that the congressional intentions were as stated. Ibid.

80 In re Turner, 24 Fed. Cas. 337 (No. 14247) (C.C.D. Md. 1867). This was a habeas corpus application made on behalf on an eleven year old Negro girl, an ex-slave, seeking "relief from restraint and detention" under which she was allegedly being held by her former master under the purported authority of an indenture of apprenticeship, executed by the girl's mother two days after the girl had been emancipated from slavery by the new constitution of Maryland. The ground of the petition was that the statute of Maryland regulating the indenturing of Negro apprentices, being more onerous than the corresponding statute relating to white apprentices, was repugnant to the Civil Rights Act of 1866 , and was moreover unconstitutional as imposing involuntary servitude in violation of the thirteenth amendment. Mr. Chief Justice Chase, sitting at circuit, sustained the petition on 
That it could not have been intended to implement the fifteenth amendment is clear. ${ }^{81}$ Could it have been intended to implement the fourteenth amendment's due process and equal protection clauses? ${ }^{82}$

The contemporary sources furnish no evidence that such was the intention. Although the habeas bill was passing through the House at the very time that the fourteenth amendment, which also originated in the House, was also clearing that body, in the discussion of neither measure was reference made to the other. The Senate discussion of the two measures, both of which were considered in the closing weeks of the session, is equally devoid of such reference. The habeas bill was drafted by the House Judiciary Committee; the amendment was drafted by the Joint Committee on Reconstruction. The chairman of neither the House nor the Senate Judiciary Committees was a member of the Joint Committee on Reconstruction, nor was Lawrence, the putative draftsman of the habeas measure. Only one member of the House Judiciary Committee and two members of the Senate Committee were also members of the Committee on Reconstruction. ${ }^{83}$ The habeas bill was introduced before the proposed fourteenth amendment had been considered by the Senate, ${ }^{84}$ which, several weeks later, proposed important changes in it, to which the House agreed. ${ }^{85}$ Neither in the proceedings of the Joint Committee on Reconstruction, ${ }^{86}$ nor in the extended congressional debates upon the fourteenth amendment was

both grounds, and ordered the petitioner released. The circumstances under which the child had been indentured, as set forth in Chase's opinion, are of interest. "Almost immediately" after the new state constitution went into effect on Nov. 1, 1864, "many of the freed people of Talbot County were collected together under some local authority, the nature of which does not clearly appear, and the younger persons were bound as apprentices, usually, if not always, to their late masters." 24 Fed. Cas. at 339.

81 The fifteenth amendment was not proposed by Congress until two and a half years after the introduction of the habeas measure in Congress, and two years after its enactment. Chronology aside, the habeas corpus remedy of course has no specific relevance to the problem of enforcing the right to vote.

82 The express statement that the statute was "passed to implement the fourteenth amendment's 'due process' and 'equal protection' clauses" is made in Note, Federal Habeas Corpus Review of State Convictions: An Interplay of Appellate Ambiguity and District Court Discretion, 68 YALE L.J. 98 (1958). WARREN and HART \& WrehsLER are cited as authority for this statement, but fail to support it. See note 68 supra. Similarly, the statement that "The act was plainly intended to help safeguard the new . . . constitutional rights created after the Civil War," is made in Pollak, Proposals to Curtail Federal Habeas Corpus for State Prisoners: Collateral Attack on the Great Writ, 66 YALE L.J. 50, 52 n.9 (1956), citing Note, supra note 68, 61 HARv. L. REv. 657 (1948).

83 Cong. Directorr, 39th Cong., 2d Sess. 53, 55, 57, 61 (2d ed. 1867).

84 Cong. Globe, 39th Cong., Ist Sess. 4228 (1866).

85 Cong. Globe, 39th Cong., 2d Sess. 903 (1867).

86 The journal of the committee's proceedings is reproduced in KENDRICK, THE JourNal of THE JoINT CoMmitte of FifteEn ON RECONSTRUCTION 37-128 (1914). Kendrick's extensive commentary contains no reference to the habeas corpus act. 
there any mention of the habeas act. And the two monographic historians of the amendment, ${ }^{87}$ to say nothing of the general historians of the period, fail to mention it. As a historical statement, therefore, the Court's assertion is a naked ipse dixit.

With factual support wholly absent, what are the probabilities that the House Judiciary Committee, charged with a House mandate to draft legislation to enforce the thirteenth amendment, drafted a bill also to vindicate rights eventually to be created by a proposed constitutional amendment, the terms of which were still a matter of disagreement with the Senate and which could not in any case become effective for months? Such a departure from the Committee's instructions, about which it said nothing in its report to the House, would surely have been inexplicable. It seems safe to conclude that it did not take place.

But there are reasons more weighty than these to doubt that the draftsman of the habeas measure, or any of its proponents, had in mind its possible utilization as a remedy for denials of due process of law or of equal protection of the laws. This could have been their intention only if they foresaw an expansion of the due process clause that was still decades in the future. ${ }^{88}$ Had Lawrence and his colleagues, moved by prophetic insight, undertaken to secure federal rights yet undreamed of, the habeas corpus proceeding would doubtless have been the last proceeding to occur to them as suitable for their purpose. ${ }^{89}$ They would assuredly have devised instead a new procedure clearly adapted to the purpose. That the judiciary committees did not shrink from such procedural innovation is clear from the radical removal and retrial procedures which they wrote into the statutes to protect federal officers and agents against oppressive state proceedings. ${ }^{90}$

If it were plain ${ }^{91}$ when the fourteenth amendment was before the

87 Flack, The Adoption of the fourteenth Amendment (1908); James, The Framing of THE FouRteENTH AMENDMENT (1956).

88 They would further have had to determine to "furnish a method additional to and independent of direct Supreme Court review of decisions for the vindication of the new constitutional guarantees" whose future development they thus prophetically envisioned-a purpose for which, the Court tells us, the statute was plainly designed. Fay v. Noia, 372 U.S. 391,416 (1963).

89 That proceeding was at the time available to attack a conviction only if the claim was that the convicting court had lacked jurisdiction; the twentieth century doctrine that a court with unquestioned initial jurisdiction could "Iose" its jurisdiction if in the course of the proceeding it infringed the defendant's constitutional rights was sixty years in the future. Johnson v. Zerbst, 304 U.S. 458 (1938).

90 See note 102 infra.

91 In Fay v. Noia, 372 U.S. 391, 420 (1963), the majority opinion declared that the doctrine "that after the state courts had decided the federal question on the merits against the habeas petitioner, he could return to the federal court on habeas and there relitigate the question" represented "unmistakable congressional intent." In Townsend v. Sain, 372 U.S. 293, 312 (1963), the majority opinion spoke of "Congress' specific aim in passing the 
states for ratification that the new habeas measure would enable the lower federal courts to reverse state convictions as a denial of due process of law, it is strange that in the historians' accounts of the prolonged and bitter resistance to the ratification of the amendment there is no mention of such a possible extension of the supervision of the lower federal courts over the high state courts. ${ }^{92}$ If it were plain, it is also odd that it was not apparent to the bar for more than half a century after the amendment had become part of the Constitution.

Rather, the clear inference from the reported cases is that it was not plain to the bar. Except for the first case, involving an ex-slave held in involuntary servitude, ${ }^{93}$ these cases invariably attacked the jurisdiction of the state court, in most cases on the grounds of the alleged unconstitutionality of the statute on which the prosecution was founded. ${ }^{94}$ It is moreover indicative of the failure of the bar to appreciate the possibilities of the 1867 statute that in a number of state criminal proceedings in which the defendant's counsel could have attacked the constitutionality of the dispositive statute at the outset by habeas corpus in the lower federal court, ${ }^{95}$ counsel resorted instead to the orthodox procedure of appealing to the Supreme Court on writ of error, which was available only after the defendant's conviction. ${ }^{96}$

\section{The Statute and the Scope of Habeas Corpus Review}

It has been urged in the preceding pages that there is no foundation for the Court's assertions that the 1867 act was intended to afford a new

Act of February 5, 1865, of affording state prisoners a forum in the federal trial courts for the determination of claims of detention in violation of the Constitution."

92 E.g., Flack, The Adoption of the Fourteenth Amendient ch. 15 (1908), gives a comprehensive summary of all the available material on the ratification of the amendment by the state legislatures. The preceding chapter covers public discussion prior to ratification. In neither chapter is the habeas act mentioned.

93 In re Turner, 24 Fed. Cas. 337 (No. 14247) (C.C.D. Md. 1867). See note 80 supra.

94 In Fay v. Noia, 372 U.S. 391, 410 (1963), it was said that before 1885, when the Supreme Court's appellate jurisdiction in federal habeas corpus cases was restored, the lower federal courts "did not hesitate to discharge state prisoners whose convictions rested on unconstitutional statutes or had otherwise been obtained in derogation of constitutional rights." (Emphasis added.) The clear implication is that, in those cases in which the ground of discharge was not the unconstitutionality of the statute, it was a ground other than lack of jurisdiction of the court under whose mandate the prisoner was being held. In support of this statement, seven cases are cited as examples, id. at $410 \mathrm{n.19}$, implying that there are others. In all but two of the cases cited, the ground of discharge was the unconstitutionality of the statute; in the remaining two, In re Wong Yung Quy, 6 Sawyer 237 (C.C.D. Cal. 1880), and In re Ah Lee, 6 Sawyer 410 (D.C.D. Ore. 1880), the ground was the court's lack of jurisdiction.

95 The decision discharging the prisoner would, before 1885 , have been final. See note 44 supra.

96 An example is Hurtado v. California, 110 U.S. 516 (1884), in which the state constitution, authorizing the prosecutor to bring the defendant to trial for a felony on information instead of on grand jury indictment, was attacked as a denial of due process. 
remedy for state prisoners, that it was enacted in contemplation of anticipated southern resistance to Reconstruction, and that it was aimed at implementing the fourteenth amendment. It remains to take note of the Court's assertion that its far-reaching enlargement of the scope of this habeas remedy for convicted state prisoners in the past decademaking it available for appellate review of the state court record and for retrial of factual issues already determined in the state court-was also intended by the 1867 Congress. In 1867 it had long been settled law that on the habeas application of a convicted prisoner the only question before the court was whether the sentencing court had jurisdiction. ${ }^{.7}$ Irregularities and errors in the proceedings resulting in conviction were wholly beyond the competence of the habeas court. If it were the intent of the draftsman of the 1867 statute to make the remedy available to state prisoners under sentence of imprisonment, surely express language would have been employed. Surely also, if the draftsman thought his bill enlarged the function of the writ for state prisoners, he would have perceived that it also enlarged the function of the writ for federal prisoners. So devious a procedure for amending the 1789 act is wholly improbable.

That habeas could not be used as a substitute for appeal was until recently hornbook learning. ${ }^{98}$ Nevertheless, in the attempt to demonstrate that its latter-day expansion of the habeas proceeding for convicted prisoners is merely a reversion to former practice, the Supreme Court in Fay $v$. Noia recited 17 th century authorities to show that at common law the writ of habeas corpus had a much wider scope than is here described. ${ }^{99}$ Whatever assessment is made of the validity of the

97 See Oaks, Habeas Corpus in the States-1776-1865, 32 U. Crr. L. Rev. 243 (1965). For federal cases, see Fay v. Noia, 372 U.S. 391, 449-63 (1963) (Harlan, J., dissenting); Bator, Finality in Criminal Law and Federal Habeas Corpus for State Prisoners, 76 HARv. L. REv. $441,465-74$ (1963).

98 In The Constitution of the Untred States of America 314 (Corwin ed. 1953) this is said still to be the rule, on the basis of cases decided by the Supreme Court to June 30 , 1952. In Brown v. Allen, 344 U.S. 443 (1953), however, the Court affirmed a lower court denial of habeas based only on a review of factual issues in the state court record, the Court itself making a similar review. Three Justices dissented; but far from objecting to this use of habeas as a procedure for appellate review by the district court, the dissenting Justices, upon their own evaluation of the state court record, would have reversed the lower court and vacated the state conviction.

99 "[A]t the time that the Suspension Clause was written into our Federal Constitution and the first Judiciary Act was passed conferring habeas corpus jurisdiction upon the federal judiciary, there was respectable common-law authority for the proposition that habeas was available to remedy any kind of governmental restraint contrary to fundamental law." 372 U.S. 391, 405 (1963). The "respectable authority" cited in support of this somewhat astonishing contribution to legal history is examined with devastating effect in Oaks, Legal History in the Supreme Court-Habeas Corpus, to be published in 64 Mick. L. REv. (1966). The Noia opinion also implies that "the Framers," in providing in the Consti- 
authorities cited or of the support they lend to the Court's contention, it may be assumed that the draftsman of the 1867 statute had no thought of reviving, sub silentio, a concept of habeas corpus for prisoners under sentence which, if it had in fact existed two centuries before, was wholly unfamiliar to the lawyers of his day and presumably to the draftsman himself. It is especially unlikely that he "envisaged," to quote the language of Noia, "a remedy almost in the nature of removal from the state to the federal courts of state prisoners' constitutional contentions," 100 or that he "envisaged" a procedure, completely unprecedented in habeas cases, empowering the federal courts to try "anew" the facts previously found in the state court after trial. ${ }^{101}$

The concept of retrial of the facts in a federal court after judgment had been rendered by the state court was in fact familiar to the draftsman. Only three years before, the House Judiciary Committee, upon which he sat, had drafted and Congress had approved a measure which expressly provided for such retrial in the case of one sued or prosecuted for an act done under federal authority. ${ }^{102}$ This retrial procedure was

tution against the suspension of the privilege of the writ of habeas corpus, had in mind a writ having "the full common-law scope as we have described it." 372 U.S. at 406 . If Hamilton, one of the framers, had any such scope in mind, he thought best to say nothing of it. The Federalist No. 84 (Hamilton).

100372 U.S. at 416.

101 The opinion spoke of the "elaborate provisions in the Act [of 1867] for taking testimony and trying the facts anew ..."372 U.S. at 416 . The only provision in the act on this point is that the court "shall proceed in a summary way to determine the facts of the case, by hearing testimony ...." A contemporary construction of this provision as it is incorporated in the Revised Statutes by District Judge Blatchford, later a Justice of the Supreme Court, is illuminating: "In determining, on habeas corpus, the 'facts' of the case, the court does not determine what were the facts of the transaction which constituted the crime of which the party was convicted. It only determines whether there was an indictment, a trial, a conviction, a final judgment, a sentence and process of execution, and jurisdiction of such proceedings. It does not retry the case." In re Stupp, 23 Fed. Cas. 296, 298 (No. 13563) (C.C.S.D.N.Y. 1875). But to the Supreme Court majority in Noia, the "expansive language" of the 1867 act, of which this simple provision is presumably a part, coupled with its "imperative tone" makes "inescapable the conclusion that Congress was enlarging the habeas remedy as previously understood . . . in making its procedures more efficacious." 372 U.S. at 415 . The contention that it was the intent of the 1867 statute to confer upon the federal courts the power, on habeas corpus, to try the facts "anew" had in effect already been made by Mr. Justice Frankfurter in Brown v. Allen, 344 U.S. 443, 506 (1953), with even less supporting analysis than is offered by the Noia opinion. By contrast, Mr. Justice Jackson, in his concurring opinion in the same case, pointed out that "the historic purpose of the writ has been to relieve detention by executive authorities without judicial trial. It might have been expected that if Congress intended a reversal of this traditional concept of habeas corpus it would have said so." 344 U.S. at 533 .

102 Act of March 3, 1863, ch. 81, \& 5, 12 Stat. 757. After providing for the removal for trial to the federal circuit court of any suit or prosecution, civil or criminal, commenced in any state court, against any officer or any other person for any act allegedly done under the authority of the President or of any act of Congress "during the present rebel- 
expressly confirmed and facilitated by a measure, drafted by the same committee, which became law at the very time he was introducing the habeas measure. ${ }^{103}$ No reason is apparent why the draftsman should not have repeated in the habeas measure the express provisions of the earlier act if he now proposed the extension of the retrial procedure via habeas corpus to state criminal proceedings claimed to be in violation of still nonexistent federal constitutional rights. That he failed to do so would seem almost conclusive evidence that the then unknown notion of a retrial after judgment on habeas corpus was not within his contemplation.

\section{Conclusron}

Even without indulging in historical inquiry, one would be bound to find inherently implausible the Supreme Court's assertion that, in declaring federal habeas corpus to be a comprehensive procedure for the review of state convictions, it is merely carrying out the intentions of the Congress which enacted the 1867 statute. While the state criminal defendant enjoyed virtually no federal constitutional rights in 1867 , he did have the right, denied to the federal defendant for another quarter of a century, of review by the Supreme Court. Nevertheless one is asked to believe that the framers of the 1876 statute intended to give the state prisoner an additional review, yet a year later to entrust this additional review solely to the lower federal courts without provision for Supreme Court review.

The process by which the Court has converted the proceeding authorized by the 1867 statute into a unique and anomalous procedure for review of state court convictions has been characterized by a recent commentator as a tour de force. ${ }^{\mathbf{1 0 4}}$ Whether or not one accepts that characterization, it seems clear that the Court's claim of merely fulfilling the intentions of the 1867 Congress is without historical foundation.

\section{APPENDIX}

Act of February 5, 1867, ch. 28, 14 Stat. 385.

CHAP. XXVIII.-An Act to amend "An Act to establish the judicial Courts of the United States," approved September twenty-fourth, seventeen hundred and eighty-nine.

$B e$ it enacted by the Senate and House of Representatives of the United States of America in Congress assembled, [1] That the several courts of the United States, and the

lion," it is further provided that either party in a civil suit, and the defendant in a criminal proceeding, may "remove and transfer" the case to the circuit court "after the rendition of a judgment ... ; and the said circuit court shall thereupon proceed to try and determine the facts and the law in such action, in the same manner as if the same had been there originally commenced, the judgment in such case notwithstanding."

103 Act of May 11, 1866, ch. 80, \& 3, 14 Stat. 46.

104 Bator, Finality in Criminal Law and Federal Habeas Corpus for State Prisoners, 76 HARv. L. REv. 441, 519 (1963). 
several justices and judges of such courts, [2] within their respective jurisdictions, [3] in addition to the authority already conferred by law, shall have power to grant writs of habeas corpus in all cases where any person may be restrained of his or her liberty in violation of the constitution, or of any treaty or law of the United States; [4] and it shall be lawful for such person so restrained of his or her liberty to apply to either of said justices or judges for a writ of habeas corpus, which application shall be in writing and verified by affidavit, and shall set forth the facts concerning the detention of the party applying, in whose custody he or she is detained, and by virtue of what claim or authority, if known; and the said justice or judge to whom such application shall be made shall forthwith award a writ of habeas corpus, unless it shall appear from the petition itself that the party is not deprived of his or her liberty in contravention of the constitution or laws of the United States. Said writ shall be directed to the person in whose custody the party is detained, who shall make return of said writ and bring the party before the judge who granted the writ, and certify the true cause of the detention of such person within three days thereafter, unless such person be detained beyond the distance of twenty miles; and if beyond the distance of twenty miles and not above one hundred miles, then within ten days; and if beyond the distance of one hundred miles, then within twenty days. And upon the return of the writ of habeas corpus a day shall be set for the hearing of the cause, not exceeding five days thereafter, unless the party petitioning shall request a longer time. The petitioner may deny any of the material facts set forth in the return, or may allege any fact to show that the detention is in contravention of the constitution or laws of the United States, which allegations or denials shall be made on oath. The said return may be amended by leave of the court or judge before or after the same is filed, as also may all suggestions made against it, that thereby the material facts may be ascertained. The said court or judge shall proceed in a summary way to determine the facts of the case, by hearing testimony and the arguments of the parties interested, and if it shall appear that the petitioner is deprived of his or her liberty in contravention of the constitution or laws of the United States, he or she shall forthwith be discharged and set at liberty. [5] And if any person or persons to whom such writ of habeas corpus may be directed shall refuse to obey the same, or shall neglect or refuse to make return, or shall make a false return thereto, in addition to the remedies already given by law, he or they shall be deemed and taken to be guilty of a misdemeanor, and shall, on conviction before any court of competent jurisdiction, be punished by fine not exceeding one thousand dollars, and by imprisonment not exceeding one year, or by either, according to the nature and aggravation of the case. From the final decision of any judge, justice, or court, inferior to the circuit court, an appeal may be taken to the circuit court of the United States for the district in which said cause is heard, and from the judgment of said circuit court to the Supreme Court of the United States, on such terms and under such regulations and orders, as well for the custody and appearance of the person alleged to be restrained of his or her liberty, as for sending up to the appellate tribunal a transcript of the petition, writ of habeas corpus, return thereto, and other proceedings, as may be prescribed by the Supreme Court, or, in default of such, as the judge hearing said cause may prescribe; and pending such proceedings or appeal, and until final judgment be rendered therein, and after final judgment of discharge in the same, any proceeding against such person so alleged to be restrained of his or her liberty in any State court, or by or under the authority of any State, for any matter or thing so heard and determined, or in process of being heard and determined, under and by virtue of such writ of habeas corpus, shall be deemed null and void.

SEC. 2. And be it further enacted, ... [6] This act shall not apply to the case of any person who is or may be held in the custody of the military authorities of the United States, charged with any military offence, or with having aided or abetted rebellion against the government of the United States prior to the passage of this act.

* For matter omitted, see notes 18 and 54. 